\title{
ULTRASTRUCTURE OF GIARDIA DUODENALIS TROPHOZOITES GROUP FROM HAMSTER: SOME RELEVANT ASPECTS
}

\author{
MARIA INÉS L. SOGAYAR \& ELISA APARECIDA GREGORIO*
}

\author{
Departamento de Parasitologia e *Departamento de Morfologia, Instituto de Biociências, UNESP, \\ Campus de Botucatu, 18600 Botucatu, SP, Brasil
}

Trophozoites of Giardia duodenalis group obtained from fragments or scratched of hamster's mucosa were examined by transmission electron microscopy. The fine structure of the trophozoites are presented and compared with those described for other animals. Some of the trophozoites present the cytoplasm full of glycogen, rough endoplasmic reticulum-like structures and homogeneous inclusions not enclosed by membranes, recognized as lipid drops, which had not been observed in Giardia from other animals. The adhesive disk is composed of a layer of microtubules, from which fibrous ribbons extend into the cytoplasm; these ribbons are linked by layer of crossbridge filaments that shows an intermediary dense band, described for the first time in this paper. The authors regard this band as the result of the cross-bridge filaments slinding in the medium region between adjacent fibrous ribbons, and suggest a contractile activity for them. The role of the adhesive disk on the trophozoite mechanism of attachment to host mucosa is also discussed.

Key words: Giardia duodenalis - trophozoite - ultrastructure - hamster - adhesive disk

The hamster may be parasited by Giardia and there are reports describing the infection of this animal by $G$. muris (Wenrich, 1946; Castellino \& De Carneri, 1963; Grant \& Woo, 1978) or G. duodenalis (Saxe, 1954; Wantland, 1955; Sogayar, 1983).

Trophozoites of $G$. muris group from different rodents have been already investigated by electron microscopy (Friend, 1966; Soloviev \& Chentsov, 1966; Holberton, 1973, 1974; Brugerolle, 1975). This work aims to describe the ultrastructure of $G$. duodenalis group from hamster, which has never been studied before.

\section{MATERIALS AND METHODS}

Trophozoites of $G$. duodenalis were obtained from naturally infected hamsters (Mesocricetus auratus). They were previously identified by light microscope in intestinal mucosa smears stained with Heidenhain's haematoxylin. Fragments or scratches from the host's mucosa were fixed in $2.5 \%$ glutaraldehyde buffered at $\mathrm{pH}$ 7.3 with $0.1 \mathrm{M}$ phosphate buffer, post-fixed in

Supported by CNPq (403177/82).

Received 29 April 1991.

Accepted 5 August 1991.
$1 \%$ osmic acid in the same buffer, dehydrated in acetone and embedded in Araldite. The ultrathin sections were stained with uranyl acetate and lead citrate and analyzed under transmission electron microscope.

\section{RESULTS}

Trophozoites of $G$. duodenalis have an adhesive disk composed of a single layer of parallel microtubules, each of them associated to an electron dense ribbon (Fig. 1). The microtubules are linked to each other through thin filaments; between adjacent ribbons there is a layer of cross-bridge filaments that sometimes shows a slender dense intermediary band (Fig. 1a). Surrounding the adhesive disk there is the ventrolateral flange formed by an extension of the cytoplasmic dorsal portion of the parasite; the distal extremity of the flange is short and thick (Fig. 1). The marginal plate that supports the flange is not well developed and it does not penetrate into its distal extremity; there is no osmiophilic filament accompanying this structure (Fig. 3a).

The cytoplasm shows ribosomes and glycogen (Figs 2, 3b); in some trophozoites the great amount of glycogen make it difficult to visualise the internal parasite structures (Fig. 2). Nu- 


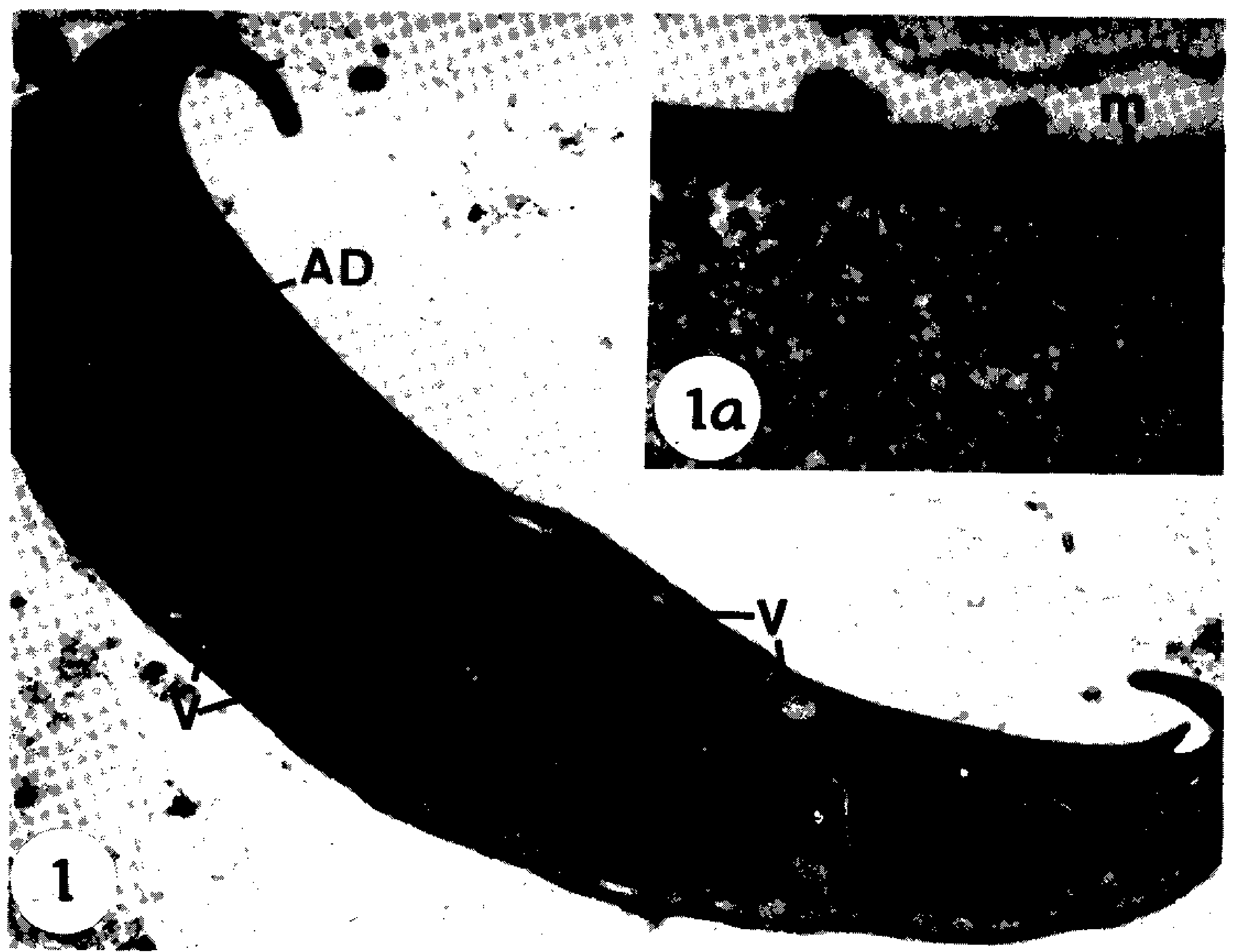

Fig. 1: general aspects of Giardia duodenalis trophozoites from hamster. Adhesive disk (AD); vacuoles (V); nucleous $(\mathrm{N})$; cytoplasmatic clefts $(\mathrm{CC})$; inclusions (i) and ventrolateral flange $(\mathrm{F}) . \mathrm{X} 28000$. Fig. 1a: detail of the ventral region of the trophozoite. Anterior flagella axoneme (a); osmiophilic material (arrow). Adhesive disk (AD) composed of microtubules (m), fibrous ribbons (double arrow) and cross bridge filaments with a dense intermediary band (b). X 75000 .

merous thin and narrow cytoplasmatic clefts can be observed (Fig. 1). Some trophozoites present rough endoplasmic reticulum-like structure (Fig. 3b) and round or ovoid inclusions of different sizes composed of homogeneous material of moderate electron density without surrounding membrane (Figs 1,2).

\section{DISCUSSION}

The general ultrastructure of $G$. duodenalis group trophozoites from hamsters presents similarities to the other species already described (Brugerolle, 1975; Kulda \& Nórynková, 1978; Sogayar, 1983; Sogayar \& Gregório, 1984, 1989). However, some of the findings in this study bring out new elements to the knowledge of the parasite morphology, which deserve a more detailed discussion.

We could observed scarse rough endoplasmic reticulum (RER) in $G$. duodenalis trophozoites. Some authors report RER-like structure in Lamblia duodenalis (Cheissin, 1964), G. muris (Brugerolle, 1975; Owen, 1980), G. lamblia (Takano \& Yardley, 1965) and in G. canis (Sogayar \& Gregório, 1984). Others, however, could not detect RER neither in $G$. muris (Erickson, 1963; Friend, 1966), nor in G. lamblia (Morecki \& Parker, 1967; Brooks et al., 1970; Tandon et al., 1974). Brugerolle (1975) suggested that the RER may be the cytoplasmatic clefts not well preserved by the fixative process. This hypothesis is supported by our observations, since the finding of typical RER was not constant and once this structure was present, it was always located in the peripheral cytoplasm.

Trophozoites of $G$. duodenalis from hamsters showed small cytoplasmic granules, identified as ribosomes (Erickson, 1963; Cheissin, 1964, 

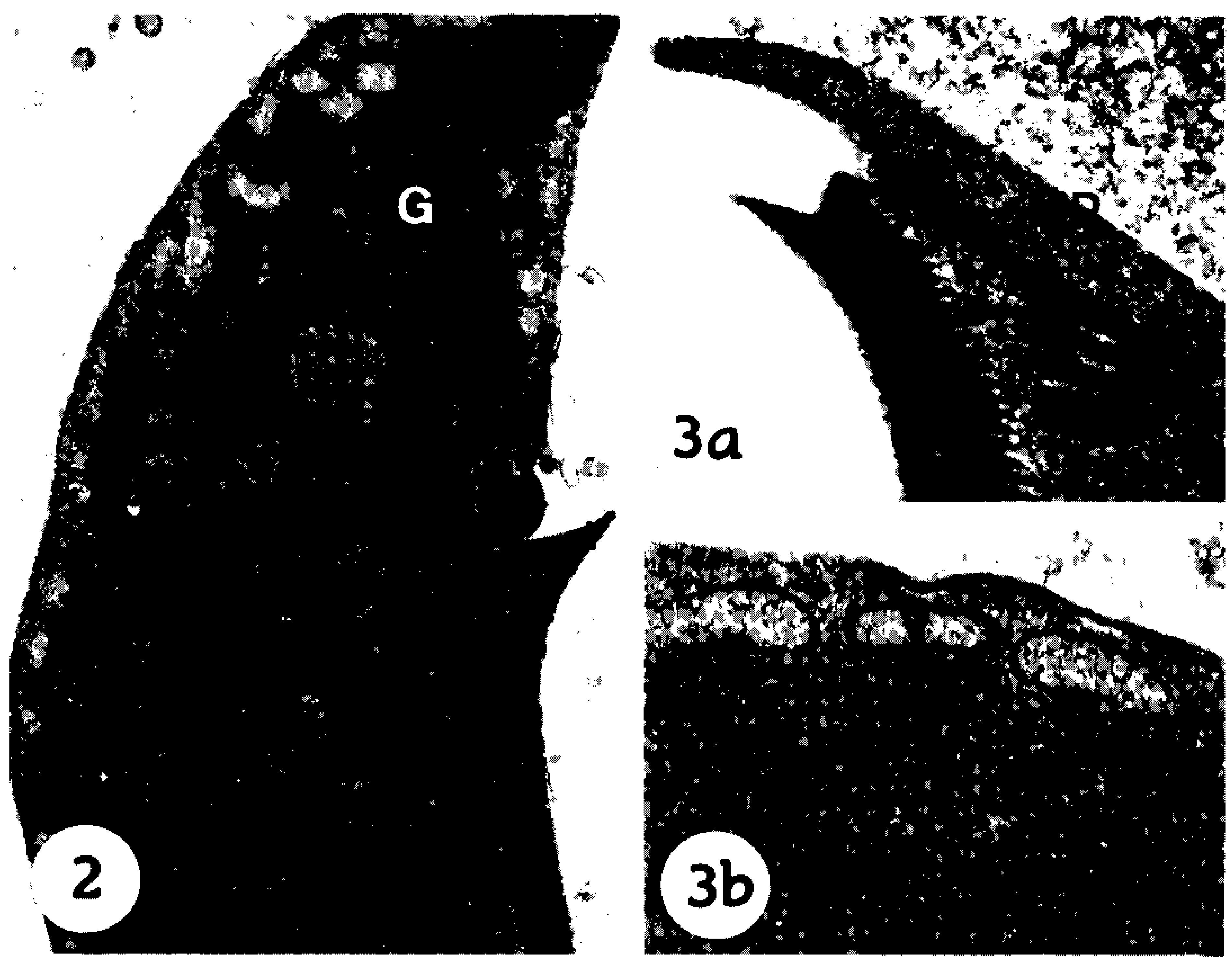

Fig 2: trophozoite full of glycogen (G) and presenting inclusions (i). X 27000. Fig. 3a: detail of the ventrolateral flange (F) with the marginal plate (MP). X 45000. Fig 3b: dorsal region of the trophozoites with vacuoles (V) and rough endoplasmatic reticulum (RER). X 53000.

Friend, 1966; Morecki \& Parker, 1967; Soloviev \& Chentsov, 1970; Tandon et al., 1974; Kulda \& Nórynková, 1978). Bigger granules similar in structure to glycogen were also observed by several authors in G. muris (Friend, 1966), $G$. duodenalis (Takano \& Yardley, 1965; Tandon et al., 1974; Kulda \& Nórynková, 1978), as well as in our material. According to Soloviev (1963), these granules could be few in some trophozoites or fill completely the cytoplasm of others, reflecting a physiological state of the parasite more than a morpho-functional difference between groups.

Inclusion of homogeneous material with moderate electron density could be found as round or oval structures not enclosed by a membrane. Similar structures were also found in $G$. duodenalis group of Rattus rattus (unpublished results) and has never been described in Giardia before. These structures bear great resemblance to lipidic drops. As they are frequently observed in trophozoites full of glycogen, it emphasizes the idea that the trophozoites showing both structures may be acumulating substances of reserve.

The fine structure of the adhesive disk has been described in detail by several authors (Friend, 1966; Holberton, 1973, 1981; Brugerolle, 1975; Feely et al., 1982). In our paper, we observed that the adhesive disk of $G$. duodenalis from hamster have the same ultrastructural aspect already described for other Giardia species. However, the adhesive disk of some trophozoites exhibited a different pattern: there was a dense intermediary band in the cross-bridges of filaments between the two adjacent fibrous ribbons. Thus, descontinuous cross-bridge filaments extend from each adjacent fibrous ribbon toward to the middle region, where they could be overlapped or not. This diversity of images observed in trophozoites from the same morphological group, might reflect different physiological states of the trophozoite adhesive disk, and allows us to 
contribute for explaining the morpho-physiology of this structure. The inter-bands image may result from the sliding of the cross-bridge filaments, as it happens with the microfilaments during the contraction of muscle cells. This idea is based on the presence of descontinuous crossbridges filaments, opposite to Peattie's (1990) proposition, who considered these filaments as continuous structures between the ribbons. Our interpretation of the contractile capacity of the cross-bridge filaments is supported by the findings of contractile proteins in the adhesive disk (Feely et al., 1982; Crossley $\&$ Holberton, 1983). The change in the adhesive disk diameter mediated by the contractile filaments may creat a negative or suction pressure with the consequent adhesion of the trophozoite to the substratum. The magnitude of this force should be modulated by the naked area, which have no microtubules.

\section{ACKNOWLEDGEMENTS}

To Maria Aparecida M. Ramos by the technical assistance, and to the Laboratorio de Microscopia Eletrônica, Instituto de Biociên. cias, UNESP, Campus de Botucatu by processing the material.

\section{REFERENCES}

BROOKS, S. E. H.; AUDRETSCH, J.; MILLER, C. G. \& SPARKE, B., 1970. Electron microscopy of Giardia lamblia in human jejunal biopsies. $J$. med. Microbiol., 3: 196-199.

BRUGEROLLE, G., 1975. Contribution a l'étude cytologique et phylétique des diplozoaires (Zoomastigophorea, Diplozoa Dangeard, 1910). V. Nouvelle interprétation de l'organisation cellulaire de Giardia. Protistologica, 11:99-109.

CASTELLINO, S. \& DE CARNERI, I,, 1963. Frequenza delle giardiasi in vari roditori da laboratorio e attecchimento delle Giardia dell'hamster nel ratto. Riv. Parasit., 24: 231-235.

CHEISSIN, E. M., 1964. Ultrastructure of Lamblia duodenalis. I. Body surface, sucking disc and median bodies. J. Protozool., 11:91-98.

CROSSLEY, R. \& HOLBERTON, D. V., 1983. Characterization of proteins from the cytoskeleton of Giardia lamblia. J. Cell Sci., 59:81-103.

DUTTA, G. P., 1965. Demonstration of neutral polysaccharides with fluorescence microscopy using acridine orange. Nature, 205: 712 .

ERICKSON, D. G., 1963. Electron microscopy of Giardia muris. J. Parasitol., 49: 38.

FEELY, D. E.; SCHOLLMEYER, J. V. \& ERLANDSEN, S. L., 1982, Giardia spp: distribution of contractile proteins in the attachment organelle. Exp. Parasitol, 53: 145-154.

FRIEND, D. S., 1966. The fine structure of Giardia muris. J. Cell Biol, 29: 317-331.

GRANT, D. R. \& WOO, P. T. K., 1978. Comparative studies of Giardia spp in small mammals in southern
Ontario. I. Prevalence and identity of the parasites with taxionomic discussion of the genus. Canad. J. Zool., 56:1348-1359.

HOLBERTON, D. V., 1973. Fine structure of the ventral disk apparatus and the mechanism of attachment in the flagellate Giardia muris, $J$. Cell Biol., 13:1141.

HOLBERTON, D. V., 1974. Attachment of Giardia, a hidrodynamic model based on flagellar activity. J. Cell Sci., 60: 207-221.

HOLBERTON, D. V., 1981. Arrangement of subunits in microribbons from Giardia. J. Cell Sci., 47: 167-185.

KULDA, J. \& NORYNKOVA, E., 1978. Giardia and Giardiasis. p. 69-138. In J. P. Kreier, Parasitic Protozoa. V. II, New York, Academic Press.

MORECKI, R. \& PARKER, J, C., 1967. Ultrastructural studies of the human Giardia lamblia and subjacent jejunal mucosa in a subject with steatorrhea. Gastroenterology, 52:151-164.

OWEN, R. L., 1980. The ultrastructural basis of Giardia function. Trans. $R$. Soc. Trop. Med. Hyg., 74:429-433.

PEATTIE, D. A., 1990. The giardins of Giardia lamblia: genes and proteins with promise. Para. sitology Today, 6: 52-56.

SAXE, L. H., 1954. The enteric protozoa of laboratory hamsters. J. Parasitol., 40: 20.

SOGAYAR, M. I. L., 1983. Observaçōes sobre Giardia Kunstler, 1882 de pequenos mamiferos de labora. tório, peridomiciliares e silvestres nas regióes de Botucatu e Conchas, SP. Prevalência, identidade $e$ aspectos biológicos dos parasitas. São Paulo. Tese de Doutoramento - Instituto de Ciências Biomédicas da Universidade de São Paulo, 159 p.

SOGAYAR, M. I. L. \& GREGÓRIO, E. A., 1984. Ultrastructure of Giardia canis trophozoites. Zbl. Vet. Med. B., 31: 107-114.

SOGAYAR, M. I. L. \& GREGÓRIO, E. A., 1989. Giardia muris and Giardia duodenalis groups: Ultrastructural differences between the trophozoites. Rev. Inst. Med. Trop. S. Paulo, 31:242247.

SOLOVIEV, M. M., 1963. Cytochemical study of Lamblia duodenalis. Med. Parazit., (Mosk.), 32; $675-678$.

SOLOVIEV, M. M. \& CHENTSOV, J. S., 1966. Electron microscope study of Lamblia muris with regard to peculiarities of the ecology of the parasite. Med, Parazit. (Mosk.), 35:667-672.

SOLOVIEV, M. M. \& CHENTSOV, J. S., 1970. Ultrastructure of cysts of Lamblia muris. Parasitologya, $4: 510-514$.

TAKANO, J. \& YARDLEY, J. H., 1965. Jejunal lesions in patients with giardiasis and malasorption. An electron microscopy study. Bull. Johns Hopk. Hosp., l16: 413429.

TANDON, B. N.; PURIT, B. K.; GANDHI, P. C. \& TEWARI, S. G., 1974. Mucosal surface injury of jejunal mucosa in patients with giardiasis: an electron microscopic study. Indian J. Med. Res., 62: 1838-1842.

WANTLAND, W. W., 1955. Parasitic fauna of the golden hamster. J. dent. Res., 34:631-649.

WENRICH, D. H., 1946. Cultural experiments on intestinal flagellates. I. Trichomonad and other flagellates obtained from man and certain rodents. J. Parasitol., 32: 40-53. 